\title{
Cost of German Scientific Publications
}

$\mathrm{T}$ HE high prices of German scientific publications, to which reference has been made in Nature $(132,34$ and $540 ; 1933)$, are again discussed in Angewandte Chemie of March 9 . The chief factors in the increased cost are the decreased demand, increased cost of paper, binding, type and setting and illustrations, as well as overhead charges, decreased revenue from advertisements resulting from diminished circulation, the publication of smaller editions to avoid getting out of date, with consequent heavier on-costs, and the high discounts afforded to German booksellers. It is asserted that every effort is being made at compression to compensate for the 15-20 per cent greater space normally required for a German book as compared with the same work in French or English, and that the 'Münster Agreement' of 1933 (between librarians, publishers and the university unions, representing the authors) has in this way already resulted in an estimated decrease of $2,000,000$ gold marks in costs of publication.

The prices of books and journals have been reduced, but only exceptionally has the cost per page been reduced, chiefly due to the technical costs of production which are not under the publisher's control. It is estimated that the cost of setting and printing is about 95 per cent above that of 1913 ; plates and line blocks are 60 and 150 per cent dearer, paper 12 pər cent and bookbinding 100 per cent above the 1913 charges, representing an average increase of 50 per cent, or more for many important books. Author's fees have also increased, but are being reduced, and are now little above the pre-War figure. This factor, however, reacts adversely on the demand, since authors form an appreciable proportion of the purchasers of scientific works. During 1934, imports of foreign journals into Germany decreased 16 per cent in volume as against 12 per cent by value, indicating increased costs of production elsewhere, while exports of German literature decreased by $13 \cdot 1$ per cent in volume and $16 \frac{1}{3}$ per cent in value, indicating a fall in German prices.

On-costs in particular have increased both actually and relatively, and are still tending to rise owing to industrial conditions and diminished output. Publicity charges are more than 50 per cent higher than in 1913 , taxation is at least four times as great, rents are 20 per cent, heating and lighting 27 per cent higher, and 20 per cent of the turnover in advertisements has to be contributed to the trade council. Postage charges are about 20 per cent higher and for such journals as Angewandte Chemie and Die Chemische Fabrik amount to 15 per cent of the total cost of publication. Salaries and wages are estimated at 25-100 per cent above the 1913 level. The size of editions is one of the most difficult problems confronting the publisher. Profits can only be made on sales in excess of a certain minimum, and to promote sales by diminishing costs, endeavours have been made to issue new editions of textbooks every seven or eight years instead of three or four years, but there are limits to such efforts imposed by the rapidity of scientific developments. Foreign sales have diminished enormously for political reasons as well as through increased competition, and for reasons similar to those operating internally. Advertisement revenue has assisted considerably in the reduction of the price of certain journals of applied science, but only amounts to about one third of the revenue from this source in 1929-30. Retail and wholesale booksellers in Germany demand a 25-30 per cent discount as against $15-16 \frac{2}{3}$ per cent abroad, and the trade is overcrowded. The reduction in the average price of German books from 8.36 to 4.32 gold marks in four years is largely due to the special cheap editions issued by the million, and is not reflected in scientific books, the purchasers of which have been heavily hit financially.

Increased purchasing power, decreased taxation and costs of production with further efforts at condensation are the only hopeful means of increasing the circulation. The American proposal to publish only the more important scientific papers, retaining the majority in manuscript and providing photostats as required, is severely criticised as fatal to publica. tion of scientific knowledge and its effective circulation.

\section{Copepods from West Greenland Waters*}

$\mathrm{A}^{\mathrm{N}}$ $\checkmark$ important collection of pelagic copepods is described by Dr. P. Jespersen from the waters west of Greenland in the Davis Strait and Baffin Bay, with one station to the south-west of Iceland. The submarine ridge across the narrow part of the Davis Strait with a maximum depth of 700 metres forms an effective barrier to the migrations into Baffin Bay of many Atlantic species the habitat of which is deeper than this; the depths to the south of the ridge exceeding 3,500 metres and the depths in Baffin Bay amounting to at least 2,000 metres. Warm Atlantic water predominates in the sea area south of the Davis Strait, but along the west coast of South Greenland the East Greenland polar current makes its way round Cape Farewell, and in the most western part of this area there are several stations, taken by the expedition, situated in the cold Labrador current.

* Meddelelser om Grønland udgivne af Kommissionen for Videnskabelige Undersøgelser i Grønland. Bd. 79, Nr. 10: The Godthaab Expedition 1928-Copepoda. By P. Jespersen. Pp. 166. (Kobenhavn: C. A. Reitzels Forlag, 1934.) $8.00 \mathrm{kr}$.
A part of the Atlantic water passes over the submarine ridge in the Davis Strait and up into Baffin Bay, where it forms an intermediate layer below the surface with a positive temperature. The bottom water of Baffin Bay has on the contrary a negative temperature of about $-0 \cdot 4^{\circ}$. The temperature conditions alone thus form a natural limit to the northward advance of certain species.

The species are divided into two main groups: those which are found in the whole area investigated and those which are exclusively, or to a predominant degree, found in the waters south of Davis Strait; 23 species being found in the first and 76 species in the second division. Davis Strait thus appears to form the northern limit of distribution for a large number of Atlantic species, and it is specially those found in fairly great depths that cease to penetrate northwards and those more frequently caught in the upper layers which occur in the whole area. Most of the species are oceanic and no species were found 